\title{
Chapter 6 \\ Regional Land Cover Monitoring System for Hindu Kush Himalaya
}

\author{
Kabir Uddin, Mir A. Matin, Nishanta Khanal, Sajana Maharjan, \\ Birendra Bajracharya, Karis Tenneson, Ate Poortinga, \\ Nguyen Hanh Quyen, Raja Ram Aryal, David Saah, \\ Walter Lee Ellenburg, Peter Potapov, Africa Flores-Anderson, \\ Farrukh Chishtie, Khun San Aung, Timothy Mayer, Sudip Pradhan, \\ and Amanda Markert
}

\subsection{Introduction}

The land cover across the HKH region is changing at an accelerated rate due to the rapid economic growth and population pressures that are impacting the long-term sustainability of ecosystems (Fig. 6.1) and their services, including food, water, and energy (Neupane et al. 2013; Wester et al. 2019; Rasul 2016; Song et al. 2018). The vast changes happening in the forested and vegetative areas are leading to changes in environmental and climatic conditions (Hansen et al. 2001). These land cover classes are critical for maintaining the Earth's surface energy balance between the atmosphere, pedosphere, and soil (Duveiller et al. 2018; Schäfer and Dirk 2011).

K. Uddin $(\bowtie) \cdot$ M. A. Matin · N. Khanal - S. Maharjan · B. Bajracharya - S. Pradhan International Centre for Integrated Mountain Development, Kathmandu, Nepal e-mail: Kabir.Uddin@icimod.org

N. Khanal · K. Tenneson · A. Poortinga · N. H. Quyen · D. Saah · F. Chishtie Spatial Informatics Group, Pleasanton, CA, USA

W. Lee Ellenburg · A. Flores-Anderson - T. Mayer · A. Markert NASA SERVIR Science Coordination Office, Huntsville, AL, USA

P. Potapov

Global Land Analysis and Discovery, University of Maryland, College Park, MD, USA

K. S. Aung

Asian Disaster Preparedness Center, Bangkok, Thailand

R. R. Aryal

Forest Research and Training Centre, Kathmandu, Nepal

D. Saah

University of San Francisco, San Francisco, CA, USA

(C) The Author(s) 2021

B. Bajracharya et al. (eds.), Earth Observation Science and Applications for Risk Reduction and Enhanced Resilience in Hindu Kush Himalaya Region,

https://doi.org/10.1007/978-3-030-73569-2_6 


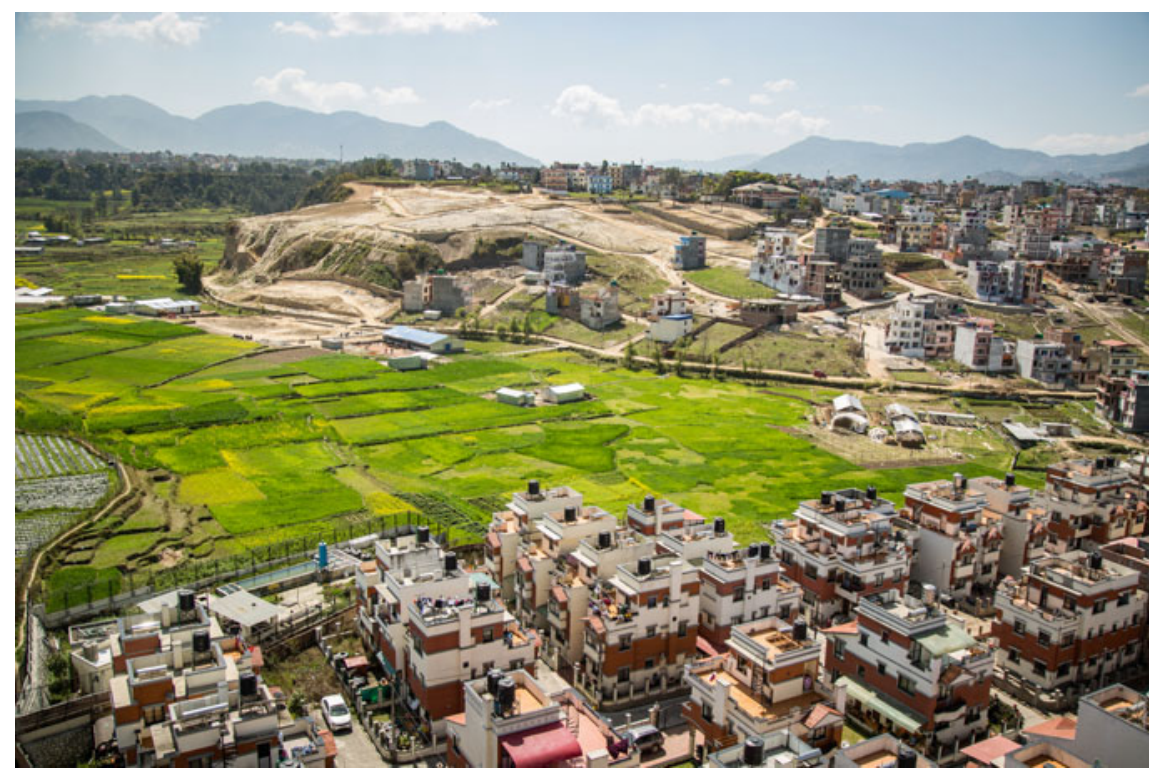

Fig. 6.1 Rapid conversion of agriculture land into built-up areas in Kathmandu valley. Photo by Jitendra Raj Bajracharya

Therefore, the accelerated changes in land cover have the potential of causing long-term impacts on many sectors in the HKH region (Xu et al. 2008, 2009).

Land cover mapping is one of the most common applications of EO, which renders meaningful information about the Earth's surface. Changes in land cover are occurring due to both natural and anthropogenic drivers and range from local to global scales. Using a land cover map, policymakers can have a better understanding of a vast landscape and the changes that are taking place in it. To estimate the historical changes over time, past land cover data for different years is critical. This change data provides vital information to land managers so that they can monitor the potential consequences of the ongoing interventions and make decisions that are right in terms of future management. The mapping of land cover and land cover change also helps to get insights into the complex interactions between human activities and global change (Running 2008; Giri 2005; Keenan et al. 2015; Uddin et al. 2015a). Global coverage at regular intervals and a wide range of spatial resolutions offered by EO satellites make them the best source of information for mapping land cover and understanding its dynamics (MacDicken et al. 2016; Estoque 2020; Giri 2012). Land cover data products are also used as a key input for various models of biodiversity, ecology, hydrology, disaster impact, food security, atmosphere, and many more (Chettri et al. 2013; Le Maitre et al. 2014; Karki et al. 2018; Ahmed et al. 2018; Carlson and Arthur 2000; Giri 2012; Uddin et al. 2020). There have been several projects related to land cover classification and change 
detection in the $\mathrm{HKH}$ region conducted by various organizations (Table 6.1) using medium resolution satellite images. However, a project-based land cover mapping does not always meet the requirements beyond the specific users involved in the mapping. Various agencies and institutions often do not share the necessary reference data which is crucial for systematic land cover mapping efforts. For decision-making purposes, the national agencies (usually the national forest departments) are mostly using single-year, often backdated, national land cover maps with limited capability to monitor in a timely or integrated fashion (Vidal-Macua et al. 2017; Kaim et al. 2016). The land cover data produced through these projects does not always fully meet the requirements of activity data for national and international reporting on the estimation of forest carbon fluxes. As a result, global land cover products are frequently used as the best available alternative when appropriate and timely maps are not available at the regional, national, or subnational levels (Gong et al. 2013). These land cover products also have limitations given they have been created using different sensors and different techniques at varying spatial resolution and classification typologies resulting in inconsistencies on global scales (Verburg et al. 2011; Bajracharya et al. 2009). These inconsistencies often hinder the practical and multiple uses of land cover layers to contribute to planning and policy formulation, as well as overall management (Ziegler et al. 2012; Skole et al. 1997; Coulston et al. 2014).

Recognizing the land cover data gaps inconsistent land cover maps in the HKH countries, ICIMOD initiated the development of regional land cover maps using a harmonized classification schema by adopting the land cover classification system (LCCS) of the FAO. During the first phase of SERVIR-HKH initiative, it developed land cover maps of 1990, 2000, and 2010 based on Landsat images using the object-based image analysis method, for the entire countries of Nepal and Bhutan and the mountain areas of Pakistan, Bangladesh, and Myanmar (Gilani et al. 2015; Qamer et al. 2016; Uddin et al. 2018, 2015). These maps made it possible to analyze changes at a decadal scale since the data for all the three years was prepared using consistent sources, classification schemes, and methodologies. At the beginning of the second phase of SERVIR-HKH, the stakeholders prioritized the need for an annual land cover monitoring mechanism called the regional land cover monitoring system (RLCMS). This was in the wake of the fact that the preparation of land cover maps using object-based segmentation requires substantial time to generate land cover data for each year. The traditional supervised classification system using desktop software also requires large computing and data storage resources. The availability of human and financial resources within these national agencies was also a major obstacle in implementing such operations. The main objective of RLCMS was to develop a system to produce annual land cover maps for the entire $\mathrm{HKH}$ region using a robust method and a harmonized classification scheme that could be updated with less human and computing resources. The specific objective was to develop the methodology and workflow, produce annual land cover maps for the years 2000-2018, and develop the capacity of the regional stakeholders to apply the relevant techniques. Co-development, co-learning, and 
Table 6.1 Land cover products in the HKH countries

\begin{tabular}{|c|c|c|c|c|c|}
\hline Country & Satellite/sensor & $\begin{array}{l}\text { Spatial } \\
\text { resolution }\end{array}$ & $\begin{array}{l}\text { Period of data } \\
\text { acquisition }\end{array}$ & $\begin{array}{l}\text { No. of } \\
\text { classes }\end{array}$ & References \\
\hline \multirow[t]{3}{*}{ Afghanistan } & $\begin{array}{l}\text { SPOT } 4 \text {, } \\
\text { Landsat TM, Aerial } \\
\text { photographs, } \\
\text { IKONOS, } \\
\text { QuickBird }\end{array}$ & $\begin{array}{l}20 \mathrm{~m} \\
30 \mathrm{~m} \\
1 \mathrm{~m} \\
1 \mathrm{~m} \\
0.6 \mathrm{~m}\end{array}$ & 2009-2011 & 11 & (FAO 2012) \\
\hline & Landsat TM & $30 \mathrm{~m}$ & 1990,1993 & 11 & (FAO 2001) \\
\hline & Aerial photographs & - & 1960-1970 & 10 & (FAO 1999) \\
\hline \multirow[t]{4}{*}{ Bangladesh } & Landsat TM & $30 \mathrm{~m}$ & 2005 & 14 & $\begin{array}{l}\text { (Altrell } \\
\text { et al. 2007) }\end{array}$ \\
\hline & Landsat MSS/ETM & $30 \mathrm{~m}$ & 1977,2000 & & $\begin{array}{l}\text { (Uddin and } \\
\text { Guring } \\
\text { 2010) }\end{array}$ \\
\hline & $\begin{array}{l}\text { NOAA AVHRR } \\
\text { HRPT }\end{array}$ & $1.1 \mathrm{~km}$ & $\begin{array}{l}\text { 1985-1986; 1992- } \\
1993\end{array}$ & 9 & $\begin{array}{l}\text { (Giri and } \\
\text { Shrestha } \\
1996)\end{array}$ \\
\hline & Landsat imagery & $30 \mathrm{~m}$ & 1981 & & (FAO 1981) \\
\hline \multirow[t]{2}{*}{ Bhutan } & ALOS & $10 \mathrm{~m}$ & $\begin{array}{l}\text { 2006-2009 winter } \\
\text { season }\end{array}$ & 11 & $\begin{array}{l}\text { (MoAF } \\
2011)\end{array}$ \\
\hline & Landsat & $30 \mathrm{~m}$ & $\begin{array}{l}\text { 1990, 2000, and } \\
2010 \text { (change } \\
\text { detection) }\end{array}$ & 10 & $\begin{array}{l}\text { (Gilani } \\
\text { et al. 2015) }\end{array}$ \\
\hline \multirow[t]{2}{*}{ China } & \multirow[t]{2}{*}{ Landsat TM } & \multirow[t]{2}{*}{$30 \mathrm{~m}$} & \multirow{2}{*}{$\begin{array}{l}\text { 1995-1996; } \\
\text { (updated in 2000, } \\
2005,2008, \text { and } \\
2010 \text { ) }\end{array}$} & \multirow[t]{2}{*}{25} & $\begin{array}{l}\text { (Liu and } \\
\text { Tian 2010) }\end{array}$ \\
\hline & & & & & $\begin{array}{l}\text { (Chen et al. } \\
\text { 2011) }\end{array}$ \\
\hline \multirow[t]{5}{*}{ India } & Landsat MSS & $80 \mathrm{~m}$ & 1984-1985 & \multirow[t]{3}{*}{14} & \multirow{3}{*}{$\begin{array}{l}\text { (Roy et al. } \\
2015 \text { ) }\end{array}$} \\
\hline & Landsat and IRS 1B & $\begin{array}{l}30 \mathrm{~m} \text { and } \\
72 \mathrm{~m}\end{array}$ & 1994-1995 & & \\
\hline & $\begin{array}{l}\text { Landsat and } \\
\text { Resourcesat I }\end{array}$ & $\begin{array}{l}30 \mathrm{~m} \text { and } \\
23.5 \mathrm{~m}\end{array}$ & $2004-2005$ & & \\
\hline & AWiFS & $56 \mathrm{~m}$ & $2005-2006$ & 18 & $\begin{array}{l}\text { (NRSA } \\
2007)\end{array}$ \\
\hline & $\begin{array}{l}\text { Resourcesat-2 LISS } \\
\text { III }\end{array}$ & $23.5 \mathrm{~m}$ & 2011-2012 & & $\begin{array}{l}\text { (NRSC } \\
2012)\end{array}$ \\
\hline Myanmar & Landsat 8 & $30 \mathrm{~m}$ & $\begin{array}{l}\text { October 2014- } \\
\text { March } 2015\end{array}$ & 11 & $\begin{array}{l}\text { (MONREC } \\
2006)\end{array}$ \\
\hline \multirow[t]{3}{*}{ Nepal } & RapidEye MSS & $5 \mathrm{~m}$ & $\begin{array}{l}\text { February-April } \\
2010 / 11\end{array}$ & 3 & $\begin{array}{l}\text { (DFRS } \\
2015)\end{array}$ \\
\hline & Landsat TM & $30 \mathrm{~m}$ & $\begin{array}{l}\text { November } 2010 \text { - } \\
\text { February } 2011\end{array}$ & 12 & $\begin{array}{l}\text { (Uddin } \\
\text { et al. 2015) }\end{array}$ \\
\hline & Aerial photograph & - & 1979 & 5 & $\begin{array}{l}\text { (LRMP } \\
1986)\end{array}$ \\
\hline Pakistan & SPOT 5 & $2.5 \mathrm{~m}$ & $2007-2008$ & 19 & (PFI 2012) \\
\hline
\end{tabular}


joint validation pathways were also planned to ensure the sustainability of the system. The generated land cover data was then disseminated through a customized application.

\subsection{The Approach of RLCMS}

As SERVIR HKH initiative transitioned to the second phase, land cover mapping was still one of the priorities. Specifically, the stakeholders, and they were interested in having updated maps at more frequent intervals than those of decades. It was the time when cloud computing was evolving as a strong platform for large-volume image analysis, and the University of Maryland (UMD) and the World Resources Institute (WRI) had set an example by implementing Global Forest Watch using GEE. Around the same time, the newly established SERVIR-Mekong, led by the Asian Disaster Preparedness Center, was conceptualizing and building the RLCMS for Lower Mekong region. The approach and methodology have been published in Saah et al. (2020), and Khanal et al. (2020). The RLCMS adopted a modular architecture built on the GEE computational platform which applied cloud computing and storage frameworks and thus enabled parallel calculations on a large series of data. This made it possible to generate land cover maps at national and regional scales more efficiently and at any desired temporal frequency. Realizing the changing paradigm in land cover mapping technologies and the benefits offered by GEE, SERVIR-HKH and SERVIR-Mekong joined hands to collaborate on expanding the RLCMS to the HKH region. To enable these systems the GEE outreach team provided cloud storage facilities and technical expertise. The basic structure of RLCMS was co-developed through a series of user engagements from 2016 to 2017 in the Mekong region which was later extended to the HKH region in 2018. The details of the RLCMS approach are outlined in Khanal et al. (2020); Saah et al. (2019), while the land cover methods are provided in Saah et al. (2020).

The key highlight of the RLCMS approach is co-development through partnerships and stakeholder engagements which ensure a sense of ownership and trust in developing land cover maps. The joint working environment has enabled a pathway for capacity development in terms of the sustainability of RLCMS (Saah et al. 2019). In the partnership configuration, SERVIR-Mekong and SERVIR-HKH are the regional hubs responsible for implementing the system with regional and country partners in the Lower Mekong and HKH regions, respectively. NASA, the United States Forest Service (USFS), the University of San Francisco (USF), and the GEE outreach team provided the technical assistance for developing the algorithms and implementing them in GEE. NASA also continues to collaborate with the FAO for development of an online reference data collection system called Collect Earth Online (CEO). Collaboration with FAO continues to implement the RLCMS framework in FAO SEPAL (System for Earth Observation Data Access, Processing and Analysis for Land Monitoring) in order to build a user-friendly 
interface for the RLCMS. This collaborative process has provided opportunities by leveraging the best practices and the most advanced state-of-the-art technologies on land cover mapping (Saah et al. 2019b). Besides, there were additional collaborations for specific needs, for example, the University of Maryland supported to customize a tree cover algorithm for producing data on tree cover and height.

To address the different needs of the various stakeholders, the RLCMS approach adopted five key principles: exercising flexibility to accommodate the requirements of land cover typologies; maintaining consistency across time and space; regarding remote sensing data as the source; understanding measurable uncertainty; and developing capacities (Saah et al. 2019).

A recent trend on image analysis shows that GEE is growing widely as an analysis platform because it provides publicly available multi-petabyte satellite imagery at planetary scales without any cost. It is also highly efficient in comparison to desktop, server-based image processing, and is capable of processing vast areas immediately (Saah et al. 2020; Duan et al. 2020; Mahdianpari et al. 2019; Uddin et al. 2020). Building upon GEE as its core, RLCMS incorporates the needs of each country and maintains consistency and transparency using contemporary, robust methods, and provides user-friendly analysis tools and products, besides helping build the capacity of the partners (Saah et al. 2019).

\subsection{Methods of Land Cover Mapping}

The overall methodology of the RLCMS and its eight stages, as outlined in Fig. 6.2, are: defining the land cover classification system and land cover typology; collecting land cover training samples; selection of Landsat imagery, image correction, and preparation of annual composites; selection of additional thematic data, and creation of image indices and covariates to make input layers for machine learning; utilization of supervised machine learning algorithms and creation of land cover primitives, and primitives evaluation and smoothing; evaluation of annual tree canopy and height; preparation of customized land cover maps by modifying the assemblage logic using a decision tree; and validation of the land cover maps and assessment of their accuracy. The steps are described in the following sections.

\subsubsection{Defining the RLCMS Classification Schemes and Primitives}

Defining an appropriate classification system is the first step in developing RLCMS, as a land cover map with a well-defined legend can provide useful information on the geographical status of a specific area. Classification systems can describe land 


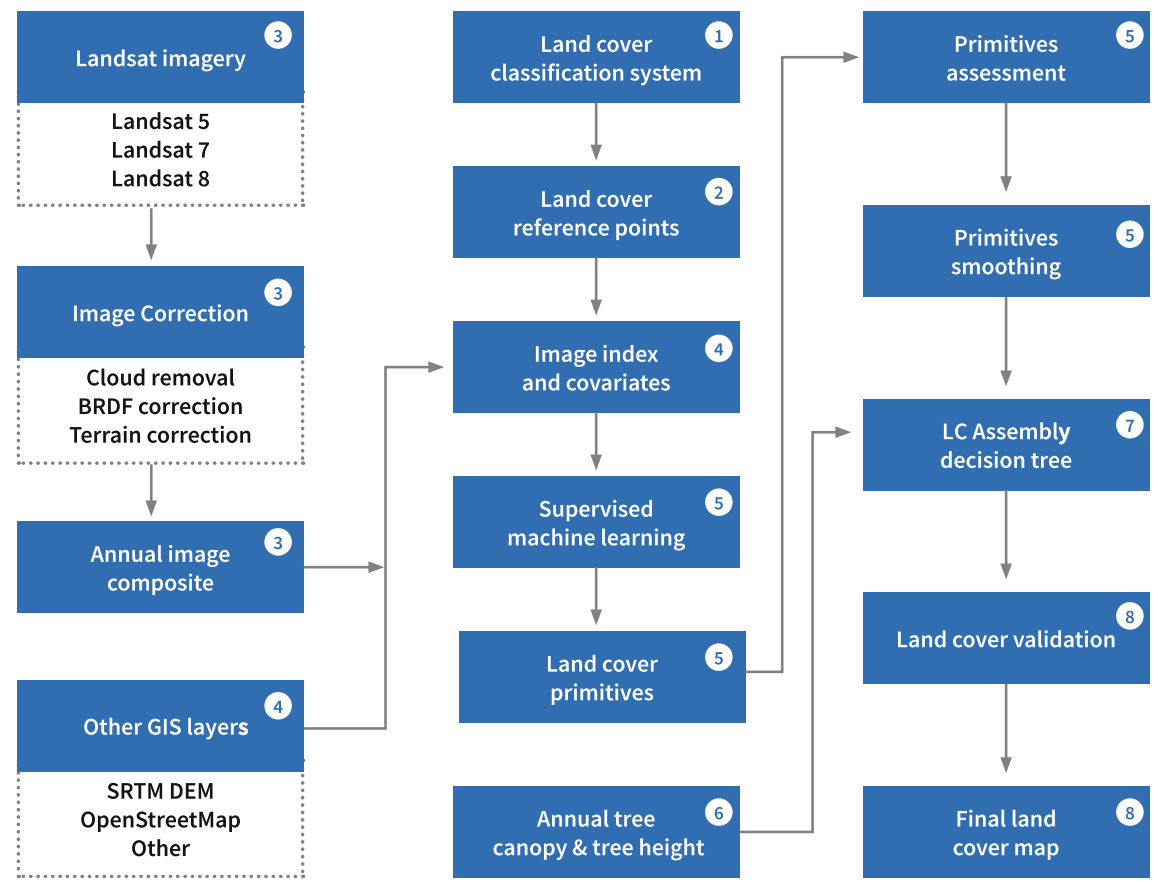

Fig. 6.2 Methodological framework for regional land cover mapping

cover features all over the world at any scale or level of detail. To identify land cover typology and to define the legend for RLCMS, the land cover classification system version 3 (LCCS 3), developed by the FAO (Di Gregorio 2016; Bajracharya et al. 2010; Gregorio 2005), was used. The LCCS provides a framework and assists users in systematically defining land cover categories through specific, observable land cover characteristics or attributes, along with the identification of their spatial and temporal relationships. The LCCS-based classification scheme utilizes the land cover element known as a primitive and employs biophysical entities that can be mapped and assembled into a final land cover map. Primitives are defined as the building blocks or the basis of a land cover class in the RLCMS approach (Saah et al. 2020). There can be one or more primitives for a particular land cover class. The definitions of land cover classes used for RLCMS with the corresponding primitives are given in Table 6.2, which are comparable for international reporting requirements for the countries and recommended by the IPCC (Penman et al. 2003).

For the development of this harmonized land cover classification system for the $\mathrm{HKH}$ region, different national and regional consultation workshops (Chap. 3) were conducted across the region involving professionals from key agencies. During the workshops, the stakeholders identified their needs as per land cover typology. At 
the regional scale, ten classes were defined (Table 6.2) to develop land cover maps for the whole of the HKH region. When the system was implemented at the national level to develop a National Land Cover Monitoring System (NLCMS), customized schemes were defined in consultation with the national stakeholders.

Table 6.2 Definitions of land cover classes

\begin{tabular}{|c|c|c|c|c|}
\hline $\mathrm{S} / \mathrm{N}$ & $\begin{array}{l}\text { Land } \\
\text { cover } \\
(\text { LCSS) }\end{array}$ & Description & $\begin{array}{l}\text { Comparability } \\
\text { to IPCC class }\end{array}$ & $\begin{array}{l}\text { RLCMS } \\
\text { Primitives }\end{array}$ \\
\hline 1 & Forest & $\begin{array}{l}\text { Land spanning more than } 0.5 \text { ha with } \\
\text { trees higher than } 5 \mathrm{~m} \text { and a canopy of } \\
\text { more than } 10 \% \text {, or trees able to reach } \\
\text { these thresholds in situ. It does not } \\
\text { include land that is predominantly under } \\
\text { crop land or large settlement areas }\end{array}$ & Forest & $\begin{array}{l}\text { Tree } \\
\text { height, } \\
\text { tree cover } \\
\text { Tree }\end{array}$ \\
\hline 2 & $\begin{array}{l}\text { Grass } \\
\text { land }\end{array}$ & $\begin{array}{l}\text { This class describes the areas covered by } \\
\text { herbaceous vegetation with a cover } \\
\text { ranging from "closed to open" (15- } \\
100 \% \text { ). This category includes } \\
\text { rangelands and pasturelands that are not } \\
\text { considered as crop land }\end{array}$ & Grassland & Grassland \\
\hline 3 & $\begin{array}{l}\text { Crop } \\
\text { land }\end{array}$ & $\begin{array}{l}\text { This category includes arable and tillage } \\
\text { land and agroforestry systems where } \\
\text { vegetation falls below the thresholds for } \\
\text { the forest land category, consistent with } \\
\text { national definitions }\end{array}$ & Crop land & Crop land \\
\hline 4 & Built-up & $\begin{array}{l}\text { Built-up describes artificial structures } \\
\text { such as towns, villages, industrial areas, } \\
\text { airports, etc. }\end{array}$ & Settlements & $\begin{array}{l}\text { Built-up, } \\
\text { NDDBI }\end{array}$ \\
\hline 5 & $\begin{array}{l}\text { Water } \\
\text { body }\end{array}$ & $\begin{array}{l}\text { A river is a naturally flowing waterbody; } \\
\text { typically, it is elongated and has a } \\
\text { geomorphologic context. Lakes and } \\
\text { ponds of perennial standing are also } \\
\text { waterbodies }\end{array}$ & Wetlands & $\begin{array}{l}\text { Open } \\
\text { water }\end{array}$ \\
\hline 6 & $\begin{array}{l}\text { River } \\
\text { bed }\end{array}$ & $\begin{array}{l}\text { Riverbed is a tract of land without } \\
\text { vegetation surrounded by the waters of } \\
\text { an ocean, lake, or stream; it usually } \\
\text { means any accretion in a river course }\end{array}$ & & Riverbeds \\
\hline 7 & $\begin{array}{l}\text { Bare } \\
\text { soil }\end{array}$ & $\begin{array}{l}\text { A soil surface devoid of any plant } \\
\text { material }\end{array}$ & Other & Bare soil \\
\hline 8 & $\begin{array}{l}\text { Bare } \\
\text { rock }\end{array}$ & Non-vegetated areas with a rock surface & & Bare rock \\
\hline 9 & Snow & $\begin{array}{l}\text { This class describes perennial snow } \\
\text { (persistence }>9 \text { months per year) }\end{array}$ & & Snow \\
\hline 10 & Glacier & Perennial ice in movement & & Glacier \\
\hline
\end{tabular}




\subsubsection{Collection of Land Cover Training and Validation Data}

The primary reference data was collected for each year from 2000-2020 using various sources. Field campaigns were conducted in collaboration with the national partners using a mobile app. Some data was collected from previous field campaigns by the partner agencies. Additional data was collected for national land cover mapping for each country. High-resolution satellite images were used to collect samples from earlier years using the Collect Earth Desktop or the CEO platform of the FAO. The CEO supports a systematic collection of reference samples using various high- and very high-resolution satellite images as background to meet the requirements of any land cover mapping project for different years (Saah et al. 2019a). The collected 51,002 systematic sampling reference data was divided into two subsets. Randomly, $85 \%$ were used for primitives development, while $15 \%$ were used for the accuracy assessment of the primitives and the final maps in order to produce a confusion/error matrix.

\subsubsection{Satellite Image Processing and Land Cover Mapping}

GEE has archived Landsat scenes that have undergone multiple procedures such as computation of the sensor radiance, top-of-atmosphere (TOA) reflectance, surface reflectance (SR), cloud score, and cloud-free composites (Sidhu et al. 2018). The yearly mapping of the HKH land cover from 2000 to 2018 was done using images from Landsat 5 with the Thematic Mapper (TM) sensor, Landsat 7 with the Enhanced Thematic Mapper (ETM+) sensor, and Landsat 8 with the Operational Land Imager (OLI) sensor.

However, a few more important image preprocessing steps still needed to be applied (Saah et al. 2020; Khanal et al. 2020) to these Landsat images to minimize solar illumination, atmospheric noise, and topographic effects. In brief, removing clouds from the images was an obligatory step in Landsat image processing. In this cloud-removal step, the pixel-QA band and a cloud-core algorithm that used the spectral and thermal properties of clouds were used to identify and remove those pixels with cloud cover from the imagery. Besides the cloud area, the cloud shadows were removed in order to avoid misclassification of the areas. For that, the Temporal Dark Outlier Mask (TDOM) algorithm was used (Housman et al. 2018). The pixel quality attributes generated from the CFMASK algorithm (pixel-qa band) were also used for shadow masking (Foga et al. 2017; Scaramuzza et al. 2011; Housman et al. 2018). During the image processing, the correction of the bidirectional reflectance distribution function (BRDF) was also applied following an algorithm developed by Roy et al. (2016). As most of the HKH region has a complex terrain, topographic correction was done to alleviate the illumination effects from the topographic position, aspect, and slope that divert reflectance 
values in the case of similar features within different territories (Carrasco et al. 2019; Riaño et al. 2003; Tokola et al. 2001). Once the process of image correction was completed, 80 covariates were generated based on the Landsat annual composites, and SRTM DEM was then used as input to supervise the classification. Thus, the image indices collectively provided a critical parameter for classifying land cover, and this has a noticeable correlation with the particular land cover association (Zhao et al. 2017; da Silva et al. 2019).

\subsubsection{Creating Image Indices and Covariates}

Image indices and covariates are synthetic image layers usually created by multispectral satellite imagery. These indices and covariates often provide a unique distinguished value on a particular land cover that is not found in any of the other individual band. Typically, a wide range of ecological information and plant characteristics is recognized through various indices as it increases the separability of the classes of interest by improving the spectral information. Usually, mapping in the HKH landscape is a challenging task because of topographic variations and heterogenic land cover patterns. The satellite image bands and indices usually emphasize a specific phenomenon that is present in particular land cover classes. Because of that, a set of image bands and covariance matrices is required for accurate classification. In order to effectively classify the land cover map for the HKH, typical Landsat bands-Band 1, Band 2, Band 3, Band 4, Band 5, Band 6, and Band 7-and the multiple indices were used. The indices and covariates were selected from a large number of image matrices through analysis of their importance. The indices used were: normalized difference vegetation index (NDVI); normalized difference moisture index (NDMI); soil adjusted vegetation index (SAVI); atmospherically resistant vegetation index (ARVI); enhanced vegetation index (EVI); green chlorophyll index (GCI); normalized difference water index (NDWI); and bare soil index (BSI) and the SRTM DEM-based slope, aspect were used as input in the regression tree for land cover primitives formation by machine learning. All of these indices and covariates, together with land cover training sets, generated a higher probability of classifying the primitives. The definition of the above indices and corresponding references is available at the index database website (Henrich et al. 2009; Henrich and Brüser 2012).

\subsubsection{Primitives Generation by Machine Learning}

A supervised machine learning random forest algorithm was applied to produce land cover primitives. For each primitive, the corresponding confidence $(0-100)$ layer was generated. To reduce computational resources, the process of feature importance was performed to identify the covariates and indices with a stronger 
influence for each primitive. This gave a list of 15-30 bands for each classification that had the most impact on the results, which was then used as input for the classifier. Finally, generating land cover primitives, a random forest classifier was applied using the imported training sets, the Landsat image, and associated related raster layers.

\subsubsection{Annual Tree Canopy Cover and Height}

Tree and woody vegetation structure primitives include the annual tree canopy cover and canopy height maps. To improve regional consistency, the vegetation structure product was derived using the same approach as for the Lower Mekong region (Potapov et al. 2019). In order to map the woody vegetation structure, a set of LIDAR-based vegetation structure prediction models was applied regionally using the time series Landsat Analysis Ready Data (Potapov et al. 2019). Tree cover disturbances were detected separately and integrated into the structure's time series (Hansen et al. 2013).

\subsubsection{Primitives Assemblage for Land Cover Mapping}

Once the primitives were generated, a decision tree classifier was used to run through these primitives and hierarchically classify all the pixels into the final land cover classes (Fig. 6.3). After applying the decision tree, a minimum of 0.5 ha mapping units and continuous pixel counts were calculated for results throughout the study region which helped to remove any stray pixels or patches smaller than the minimum mapping unit. This whole process is referred to as primitive assemblage.

\subsubsection{Validation and Accuracy Assessment}

In order to ensure the reliability and credibility of the RS-based land cover map for the $\mathrm{HKH}$, an accuracy assessment was considered as a mandatory step. In this regard, the most appropriate method is to validate the land cover map using the ground truth data which is considered to be a more authentic reference. Besides, the spatiotemporal consistency of the land cover data and similar types of products should be evaluated over national and regional representative locations and periods. However, as the HKH region consists of a vast area with rough topography and as there is a problem of inaccessibility, a field-based land cover validation approach was not possible. So, for validation of the land cover, we had to depend on CEO as it has a collection of very high-resolution images. As for the accuracy estimate, it is 


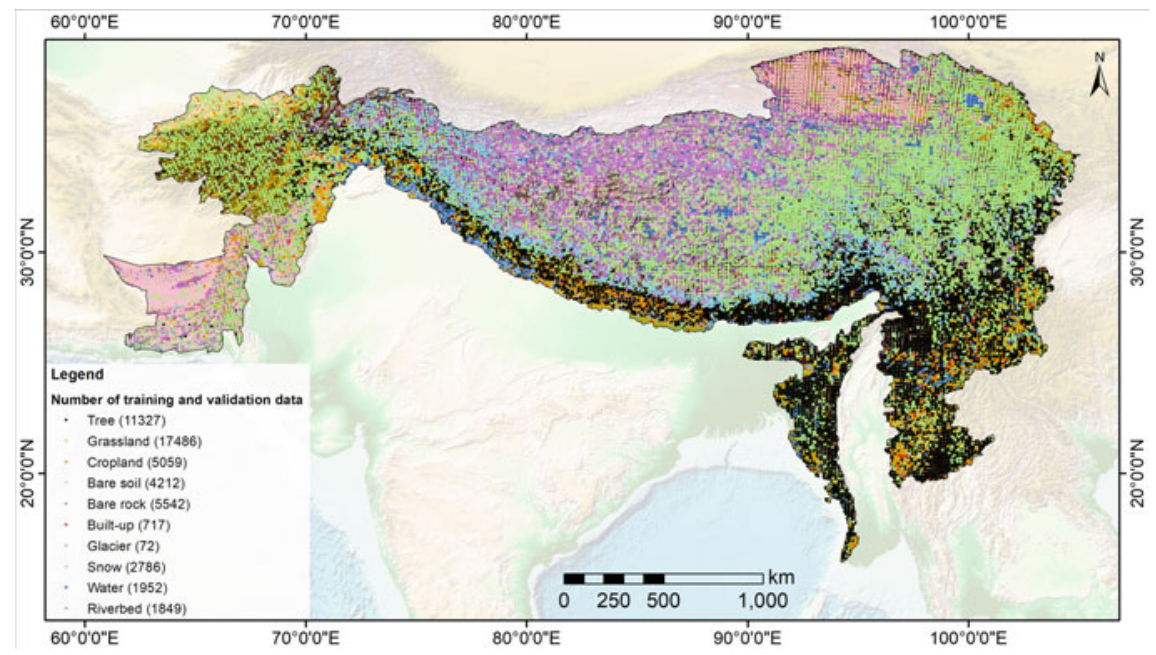

Fig. 6.3 Geographical distribution of reference data collection

derived from the error matrix generated from the validation data with their respective confidence intervals. The overall accuracy of $81.72 \%$ and the Kappa statistic values of 0.81 were achieved for the HKH land cover of 2018. These results show that the developed map datasets are reasonably accurate and agree well with high-resolution imagery (Table 6.3).

\subsection{Results}

The assembled land cover maps between 2000 and 2018 developed by RLCMS are presented in Fig. 6.4. Figure 6.5 shows the distribution of the area covered by different land covers. The results demonstrated that grassland was the most dominant land cover, followed by barren land which include areas with bare soil and bare rock. In the years 2000, 2005, 2010, and 2015, rangeland covered $37.2 \%$, $37.6 \%, 38.7 \%$, and $38.23 \%$, respectively, of the total HKH region. During the same years, the second dominant land cover was barren areas which include bare soil and bare rock. In 2000, 2005, 2010, and 2015, bare soil and bare rock together covered $32.1,31.37,30.35$, and $30.69 \%$. The assessed crop land cover in 2000 was about $5.1 \%$ and about $5.41 \%$ in 2015 . As for snow and glacier areas, they covered about $4 \%$ of the high-elevation section in 2018 , while waterbodies and riverbeds together accounted for $2 \%$. Figure 6.4 shows that topography plays an important role in natural vegetation and crop production. The weather and climatic situations also have some impact on the land cover patterns. In the HKH, forest cover is mostly 


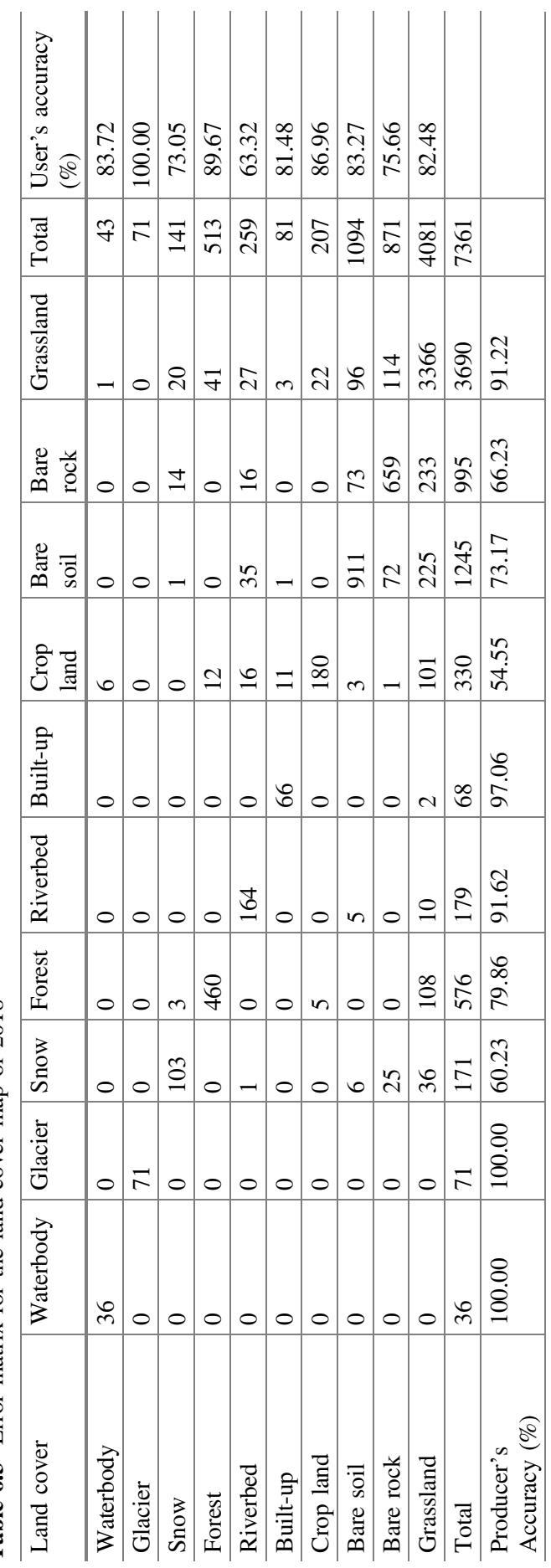




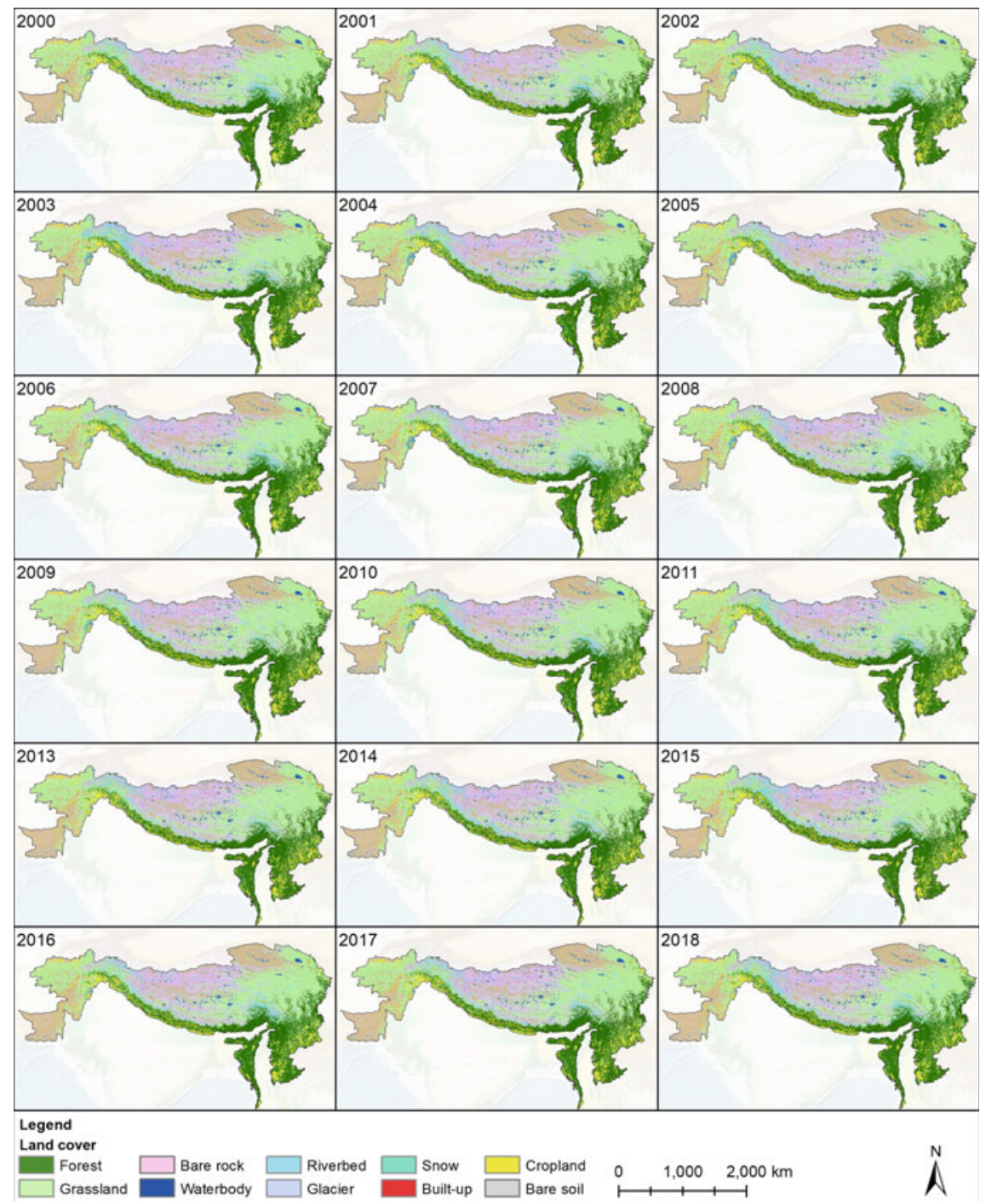

Fig. 6.4 Land cover maps of the HKH region (2000-2018)

spread in the south and south-eastern areas, where precipitation is higher; the grasslands are mostly distributed in the north and north-western parts while agricultural land is mostly found in the southern part of the region. 


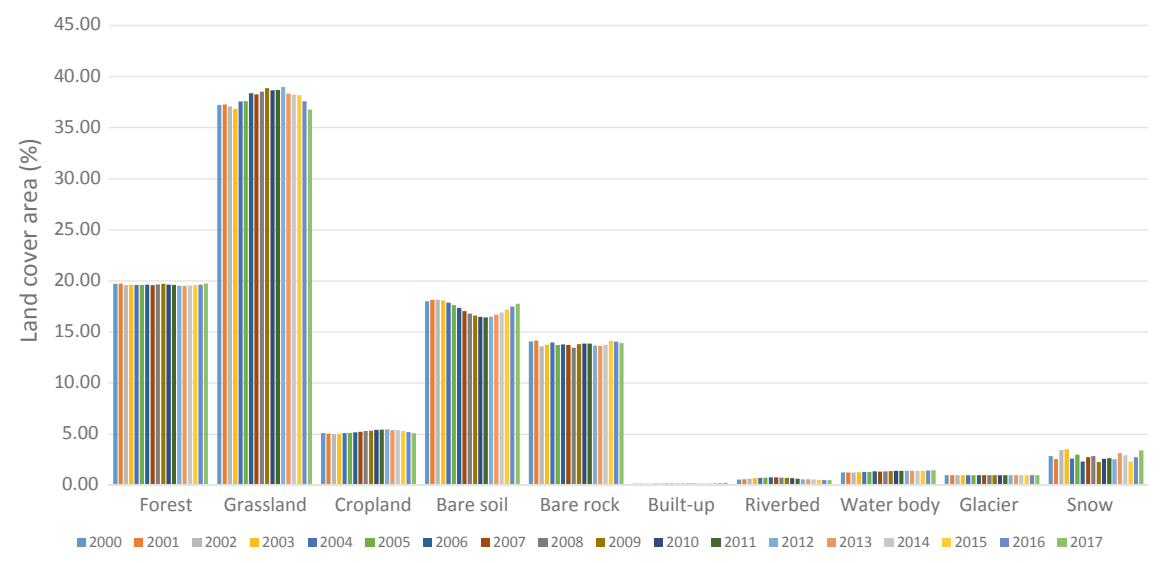

Fig. 6.5 Percentage of different land cover classes (2000-2018)

\subsection{Implementation at the Regional and National Levels}

The land cover mapping system was implemented at two levels. At the regional level, a spatially seamless and temporally consistent annual land cover maps of the whole HKH region were generated using the broad land use categories recommended by the IPCC; this is also suitable for regional-level change monitoring of carbon stock and GHG emissions (Penman et al. 2003; Li et al. 2017). However, in addition to the IPCC-specified classes, a few additional categories such as snow, bare soil, and bare rock which are important for the region have also been included.

At the national level, the system has been implemented to develop NLCMS in collaboration with the national agencies mandated for land cover mapping and monitoring. In Nepal, the system has been implemented in collaboration with the Forest Research and Training Center (FRTC). To implement RLCMS in Nepal, ICIMOD and FRTC partnered in developing the system. A technical team was formed, comprising of staff from FRTC and ICIMOD, and an advisory team too was set up consisting of senior management of FRTC and the senior leadership of SERVIR, to provide guidance. National workshops, supported by SERVIR and SilvaCarbon, were also organized with participants from most of the agencies using land cover data to get feedback on the classification scheme, data quality, and accuracy. FRTC and ICIMOD worked together for sample collection from images and fields, evaluating classification results and field validation.

In Afghanistan, a land cover map was produced by the FAO for 2010. The Ministry of Agriculture Irrigation and Livestock (MAIL) needed to update this map. Through a workshop attended by high-level officials from MAIL and other key government agencies, the RLCMS methodology and land cover legends for Afghanistan were finalized. A technical team consisting of staff from ICIMOD, MAIL, and the National Statistical Information Authority (NSIA) was formed to co-develop this map. 
In Myanmar, NLCMS has been implemented jointly by SERVIR-Mekong, SERVIR-HKH, and the Forest Department. The land cover legends were defined in consultation with the latter.

In the case of Bangladesh, the Bangladesh Forest Department (BFD) carried out a mapping project to develop land cover maps for the years 2000, 2005, 2010, and 2015. The project was implemented by the FAO with funding from USAID. The land cover legend was defined using the FAO LCCS system through country consultations. The mapping was done by interpreting SPOT and Landsat images. Then, in order to update these maps, the BFD requested ICIMOD to implement RLCMS for mapping the 2019 land cover of Bangladesh. Toward this end, fieldwork and image-based sample collections were conducted jointly by a team consisting of members from the BFD and ICIMOD.

\subsection{Challenges and Lessons Learnt}

\subsubsection{Class Definition}

The accuracy of a land cover map depends highly on the clarity and unambiguity of the class definition. Before implementing the RLCMS method for generating land cover maps, priority was accorded to document the class definition so that all the users and developers could agree on it. However, there were some classes where the partners were unsure about how to define them. The following two examples elaborate it:

- A forest is defined as an entity with "more than $20 \%$ tree crown cover and average tree height more than $5 \mathrm{~m}$ within the minimum mapping unit" (Herold et al. 2009). However, when an area within a forest has very young trees with their height less than 5 meters, there arises a problem in defining that area. While some people argue that since these trees have the potential to grow beyond 5 meters, they should be grouped as a forest, but there are others who do not agree. One issue with RS technology is that it is not capable of determining future growth; it only classifies what is currently on the ground.

- Another confusion is about the classes of "other wooded land" and "open forest." In both cases, the canopy cover is between 20 and $50 \%$.

\subsubsection{Reference Data Collection}

The accuracy of classification is also dependent on the number and quality of the reference data that are used. While in some cases, high-resolution images provide a good source of reference data, these images are not available for all the previous 
years. Besides, the accuracy of the reference data also varies with the operator collecting those data.

\subsubsection{Comparison with Legacy Data and Statistics}

The accuracy assessment of RS-based classification is usually done with statistically designed validation samples and by calculating various accuracy parameters. But in the HKH region, another issue interrupts the independent assessment of accuracy. Usually, the government agencies have the legacy data on land cover and the corresponding statistics, but they can be reluctant to accept any deviation from those earlier statistics.

\subsubsection{Limitation of the GEE Cloud Platform}

When processing the whole geographical region of the $\mathrm{HKH}$, the image volumes were too large for a desktop computer to handle. Though GEE provides the opportunity to process these large areas, sometimes processing in GEE could not be done when the number of the reference sample were too many. In such cases, processing needs to be done in batches, focusing on a smaller area at a time. Typically, GEE allows a maximum of 100 million object features and 100,000 vertices for each row's geometry.

The implementation of a few obligatory image-processing algorithms, e.g., atmospheric and topographic corrections, was easy to implement for Landsat images. In a couple of days, GEE could perform all corrections for a country without implementing image tiles options. But that said, in the case of the HKH region, it takes approximately 20 days to create composites. Among the user-defined land cover classes, distinguishing the built-up land cover class was challenging through the random forest algorithm. In this aspect, the newly conceived Normalized Difference and Distance Built-up Index (NDDBI) developed a fusion of OSM and NDVI layers to map built-up accurately (Khanal et al. 2019). Also, NDDBI index takes advantage while negating the limitations on built-up mapping.

\subsubsection{Partners' Confidence}

It was a challenging task to gain the confidence of the partner agencies to adopt the RLCMS for land cover mapping. It took some time, multiple consultations and training programs to gain their confidence as they had been involved in traditional mapping systems. To ensure that the resultant land cover data would be used by the 
partners, SERVIR focused on co-development and partnership. But this took a long time since agreements had to be arrived at through the organizational channels of the partner agencies.

\subsubsection{Sustainability and Human Resource}

Though the RLCMS relies on an automatic classification method and needs comparatively fewer human resources than the traditional image-interpretation-based land cover map production, the future update of land cover data needs a team with an understanding of the RLCMS algorithm which is based on GEE and JavaScript or Python script. At present, the partner agencies lack sufficient GIS and RS professionals with the appropriate background to update the land cover maps. Sometimes, frequent staff turnover in corresponding agencies makes it difficult for sustainable knowledge transfer on land cover mapping. Sometimes, the trained RS staff get transferred to other departments or field offices. Besides, the technical staff at the respective government agencies is engaged in other administrative work which diverts their time from working on the RLCMS.

\subsection{Conclusion and Way Forward}

The chapter has presented the SERVIR-HKH efforts in land cover mapping of the HKH region. The currently available land cover datasets in the region are not suitable for analyzing land cover changes over time due to the different classification schemes and methodologies used to generate those maps. SERVIR aimed to address this gap and develop a methodology and system to produce land cover maps on an annual basis using the same classification scheme and processing methodology. While addressing the regional needs, SERVIR also focused on addressing national needs that vary and sought to customize the method for producing land cover maps at the national level. The National Land Cover Monitoring System, or NLCMS, was customized for Afghanistan, Myanmar, and Nepal by addressing the specific needs of the national agencies which were co-developing the system with ICIMOD. The system was built and implemented upon the GEE cloud-based platform using Landsat imagery in combination with other thematic layers. The overall process laid great emphasis on collaboration and co-development with the partners to define the land cover typologies, collect reference samples, and validate the data. This chapter has mainly addressed the process, its methodology, and the primary results of the exercise in land cover mapping. In order to enable the partner agencies to produce and validate land cover maps, extensive training and co-development were conducted for sustainability of 
the system. In the future, more validation programs will be conducted in collaboration with the national partners. Further modifications will also be made to increase the number of classes so that additional requirements are met.

\section{References}

Ahmed B, Rahman M, Islam R, Sammonds P, Zhou C, Uddin K, Al-Hussaini TM (2018) Developing a dynamic Web-GIS based landslide early warning system for the Chittagong Metropolitan Area, Bangladesh. ISPRS Int J Geo-Info 7(12):485

Altrell D, Saket M, Lyckeback L, Piazza M, Ahmad I, Banik H, Hossain A, Chowdhury R (2007) National forest and tree resources assessment 2005-2007

Bajracharya B, Uddin K, Shrestha B (2009) Land cover mapping in the HKKH region-cases from three mountain protected areas. International centre for integrated mountain development Kathmandu

Bajracharya B, Uddin K, Chettri N, Shrestha B, Siddiqui SA (2010) Understanding land cover change using a harmonized classification system in the Himalaya. Mt Res Dev 30(2):143-156. https://doi.org/10.1659/MRD-JOURNAL-D-09-00044.1

Carlson TN, Arthur ST (2000) The impact of land use - land cover changes due to urbanization on surface microclimate and hydrology: a satellite perspective. Global Planet Change 25(1-2): $49-65$

Carrasco L, O'Neil AW, Morton RD, Rowland CS (2019) Evaluating combinations of temporally aggregated Sentinel-1, Sentinel-2 and Landsat 8 for land cover mapping with Google Earth Engine. Remote Sensing 11(3):288

Chen J, Chen J, Gong P, Liao A, He C (2011) Higher resolution global land cover mapping. Geomatics World 2:12-14

Chettri N, Uddin K, Chaudhary S, Sharma E (2013) Linking spatio-temporal land cover change to biodiversity conservation in the Koshi Tappu Wildlife Reserve, Nepal. Diversity 5(2):335-351

Coulston JW, Reams GA, Wear DN, Brewer CK (2014) An analysis of forest land use, forest land cover and change at policy-relevant scales. Forestry 87(2):267-276

da Silva VS, Salami G, da Silva MIO, Silva EA, Monteiro Junior JJ, Alba E (2019) Methodological evaluation of vegetation indexes in land use and land cover (LULC) classification. Geol Ecol Landscapes 1-11

DFRS (2015) State of Nepal's forests. Forest resource assessment (FRA) Nepal. Department of Forest Research and Survey (DFRS). Kathmandu, Nepal

Di Gregorio A (2016) Land cover classification system: classification concepts. Software version 3

Duan Y, Li X, Zhang L, Chen D, Ji H (2020) Mapping national-scale aquaculture ponds based on the Google Earth Engine in the Chinese coastal zone. Aquaculture 520:

Duveiller G, Hooker J, Cescatti A (2018) The mark of vegetation change on Earth's surface energy balance. Nature Commun 9(1):679

Estoque RC (2020) A review of the sustainability concept and the state of SDG monitoring using remote sensing. Remote Sensing 12(11):1770

FAO (1981) Land cover indications derived from Landsat imagery. FAO. http://www.fao.org/ geonetwork/srv/en/main.home?uuid=5879a4f0-8fdf-4c93-b39a-02d6ce69ae6d, 2019

FAO (1999) Land Cover of Afghanistan (1972). FAO. http://www.fao.org/geonetwork/srv/en/ main.home?uuid=5879a4f0-8fdf-4c93-b39a-02d6ce69ae6d, 2019

FAO (2001) Land Cover of Afghanistan (1993). FAO. http://www.fao.org/geonetwork/srv/en/ main.home?uuid=5879a4f0-8fdf-4c93-b39a-02d6ce69ae6d, 2019

FAO (2012) Aggregated land cover database of the Islamic Republic of Afghanistan (2010). FAO. http://www.fao.org/geonetwork/srv/en/main.home?uuid=5879a4f0-8fdf-4c93-b39a02d6ce69ae6d, 2019 
Foga S, Scaramuzza PL, Guo S, Zhu Z, Dilley RD Jr, Beckmann T, Schmidt GL, Dwyer JL, Hughes MJ, Laue B (2017) Cloud detection algorithm comparison and validation for operational Landsat data products. Remote Sens Environ 194:379-390

Gilani H, Shrestha HL, Murthy M, Phuntso P, Pradhan S, Bajracharya B, Shrestha B (2015) Decadal land cover change dynamics in Bhutan. J Environ Manage

Giri C (2005) Global land cover mapping and characterization: present situation and future research priorities. Geocarto Int 20(1):35-42. https://doi.org/10.1080/10106040508542334

Giri CP (2012) Remote sensing of land use and land cover: principles and applications. CRC press

Giri C, Shrestha S (1996) Land cover mapping and monitoring from NOAA AVHRR data in Bangladesh. Int J Remote Sens 17(14):2749-2759

Gong P, Wang J, Yu L, Zhao Y, Zhao Y, Liang L, Niu Z, Huang X, Fu H, Liu S, Li C, Li X, Fu W, Liu C, Xu Y, Wang X, Cheng Q, Hu L, Yao W, Zhang H, Zhu P, Zhao Z, Zhang H, Zheng Y, Ji L, Zhang Y, Chen H, Yan A, Guo J, Yu L, Wang L, Liu X, Shi T, Zhu M, Chen Y, Yang G, Tang P, Xu B, Giri C, Clinton N, Zhu Z, Chen J, Chen J (2013) Finer resolution observation and monitoring of global land cover: first mapping results with Landsat TM and ETM + data. Int J Remote Sens 34(7):2607-2654. https://doi.org/10.1080/01431161.2012. 748992

Gregorio AD (2005) Land cover classification system classification concepts and user manual Software version (2). Food and Agriculture Organization of the United Nations, Rome

Hansen AJ, Neilson RP, Dale VH, Flather CH, Iverson LR, Currie DJ, Shafer S, Cook R, Bartlein PJ (2001) Global change in forests: responses of species, communities, and biomes: interactions between climate change and land use are projected to cause large shifts in biodiversity. Bioscience 51(9):765-779

Hansen MC, Potapov PV, Moore R, Hancher M, Turubanova S, Tyukavina A, Thau D, Stehman S, Goetz S, Loveland TR (2013) High-resolution global maps of 21st-century forest cover change. Science 342(6160):850-853

Henrich V, Brüser K (2012) Index database a database for remote sensing indices. Institute of Crop Science and Resource Conservation, University of Bonn, 2019

Henrich V, Götze E, Jung A, Sandow C, Thürkow D, Gläßer C (2009) Development of an online indices database: motivation, concept and implementation. In: Proceedings of the 6th EARSeL imaging spectroscopy sig workshop innovative tool for scientific and commercial environment applications, Tel Aviv, Israel. pp 16-18

Herold M, Hubald R, Di Gregorio A (2009) Translating and evaluating land cover legends using the UN Land Cover Classification System (LCCS). GOGC-GOLD Report 43

Housman IW, Chastain RA, Finco MV (2018) An evaluation of forest health insect and disease survey data and satellite-based remote sensing forest change detection methods: case studies in the United States. Remote Sensing 10(8):1184

Kaim D, Kozak J, Kolecka N, Ziółkowska E, Ostafin K, Ostapowicz K, Gimmi U, Munteanu C, Radeloff VC (2016) Broad scale forest cover reconstruction from historical topographic maps. Appl Geogr 67:39-48

Karki S, Thandar AM, Uddin K, Tun S, Aye WM, Aryal K, Kandel P, Chettri N (2018) Impact of land use land cover change on ecosystem services: a comparative analysis on observed data and people's perception in Inle Lake, Myanmar. Environ Syst Res 7(1):25

Keenan RJ, Reams GA, Achard F, de Freitas JV, Grainger A, Lindquist E (2015) Dynamics of global forest area: results from the FAO Global Forest Resources Assessment 2015. For Ecol Manage 352:9-20

Khanal N, Uddin K, Matin MA, Tenneson K (2019) Automatic detection of spatiotemporal urban expansion patterns by fusing OSM and landsat data in Kathmandu. Remote Sensing 11(19): 2296

Khanal N, Matin MA, Uddin K, Poortinga A, Chishtie F, Tenneson K, Saah D (2020) A comparison of three temporal smoothing algorithms to improve land cover classification: a case study from NEPAL. Remote Sensing 12(18):2888 
Le Maitre DC, Kotzee IM, O'Farrell PJ (2014) Impacts of land-cover change on the water flow regulation ecosystem service: invasive alien plants, fire and their policy implications. Land Use Policy 36:171-181

Li X, Chen G, Liu X, Liang X, Wang S, Chen Y, Pei F, Xu X (2017) A new global land-use and land-cover change product at a 1-km resolution for 2010 to 2100 based on human-environment interactions. Ann Am Assoc Geogr 107(5):1040-1059

Liu M, Tian H (2010) China's land cover and land use change from 1700 to 2005: estimations from high-resolution satellite data and historical archives. Glob Biogeochem Cycles 24(3)

LRMP (1986) Land system report. Land Resource Mapping Project (LRMP), Kenting Earth Sciences Limited, Canada

MacDicken K, Jonsson Ö, Piña L, Maulo S, Contessa V, Adikari Y, Garzuglia M, Lindquist E, Reams G, D'Annunzio R (2016) Global forest resources assessment 2015: how are the world's forests changing?

Mahdianpari M, Salehi B, Mohammadimanesh F, Homayouni S, Gill E (2019) The first wetland inventory map of newfoundland at a spatial resolution of $10 \mathrm{~m}$ using sentinel-1 and sentinel-2 data on the google earth engine cloud computing platform. Remote Sensing 11(1):43

MoAF (2011) Bhutan land cover assessment 2010

MONREC F (2006) Data book with the results of the project “strengthening Myanmar's national forest monitoring system- land use assessment and capacity building” (TCP/MYA/3501)

Neupane N, Murthy MSR, Rasul G, Wahid S, Shrestha AB, Uddin K (2013) Integrated biophysical and socioeconomic model for adaptation to climate change for agriculture and water in the Koshi Basin. Handbook of climate change adaptation. Springer, Berlin, Germany, pp $1-23$

NRSA (2007) National land use and land cover mapping using multi temporal AWiFS data. http:// www.fao.org/geonetwork/srv/en/main.home?uuid=5879a4f0-8fdf-4c93-b39a-02d6ce69ae6d. Accessed NRSA 2019

NRSC (2012) National land use/land cover: national level annual land use/land cover (LU/LC) maps. http://www.fao.org/geonetwork/srv/en/main.home?uuid=5879a4f0-8fdf-4c93-b39a02d6ce69ae6d. Accessed NRSA 2019

Penman J, Gytarsky M, Hiraishi T, Krug T, Kruger D, Pipatti R, Buendia L, Miwa K, Ngara Todd, Tanabe K, Wagner F (2003) Good practice guidance for land use, land-use change and forestry. The Intergovernmental Panel on Climate Change (IPCC), Kanagawa, Japan

PFI (2012) Landcover atlas of Pakistan. Pakistan Forest Institute (PFI), Peshawar, Pakistan

Potapov P, Tyukavina A, Turubanova S, Talero Y, Hernandez-Serna A, Hansen M, Saah D, Tenneson K, Poortinga A, Aekakkararungroj A (2019) Annual continuous fields of woody vegetation structure in the Lower Mekong region from 2000-2017 landsat time-series. Remote Sens Environ 232:

Qamer FM, Shehzad K, Abbas S, Murthy M, Xi C, Gilani H, Bajracharya B (2016) Mapping deforestation and forest degradation patterns in Western Himalaya, Pakistan. Remote Sens 8 (5):385

Rasul G (2016) Managing the food, water, and energy nexus for achieving the sustainable development goals in South Asia. Environ Dev 18:14-25

Riaño D, Chuvieco E, Salas J, Aguado I (2003) Assessment of different topographic corrections in Landsat-TM data for mapping vegetation types (2003). IEEE Trans Geosci Remote Sens 41 (5):1056-1061

Roy PS, Roy A, Joshi PK, Kale MP, Srivastava VK, Srivastava SK, Dwevidi RS, Joshi C, Behera MD, Meiyappan P (2015) Development of decadal (1985-1995-2005) land use and land cover database for India. Remote Sensing 7(3):2401-2430

Roy DP, Zhang H, Ju J, Gomez-Dans JL, Lewis PE, Schaaf C, Sun Q, Li J, Huang H, Kovalskyy V (2016) A general method to normalize landsat reflectance data to nadir BRDF adjusted reflectance. Remote Sens Environ 176:255-271

Running SW (2008) Ecosystem disturbance, carbon, and climate. Science 321(5889):652-653 
Saah D, Tenneson K, Matin M, Uddin K, Cutter P, Poortinga A, Ngyuen QH, Patterson M, Johnson G, Markert K (2019) Land cover mapping in data scarce environments: challenges and opportunities. Front Environ Sci 7:150

Saah D, Tenneson K, Poortinga A, Nguyen Q, Chishtie F, San Aung K, Markert KN, Clinton N, Anderson ER, Cutter P (2020) Primitives as building blocks for constructing land cover maps. Int J Appl Earth Obs Geoinf 85:101979

Scaramuzza PL, Bouchard MA, Dwyer JL (2011) Development of the Landsat data continuity mission cloud-cover assessment algorithms. IEEE Trans Geosci Remote Sens 50(4):1140 1154

Schäfer K, Dirk V (2011) The physical environment within forests. Nat Educ Knowl 2(12):5

Sidhu N, Pebesma E, Câmara G (2018) Using Google Earth Engine to detect land cover change: Singapore as a use case. Eur J Remote Sens 51(1):486-500

Skole D, Justice C, Townshend J, Janetos A (1997) A land cover change monitoring program: strategy for an international effort. Mitig Adapt Strat Glob Change 2(2-3):157-175

Song X-P, Hansen MC, Stehman SV, Potapov PV, Tyukavina A, Vermote EF, Townshend JR (2018) Global land change from 1982 to 2016. Nature 560(7720):639-643

Tokola T, Sarkeala J, Van der Linden M (2001) Use of topographic correction in Landsat TM-based forest interpretation in Nepal. Int J Remote Sens 22(4):551-563

Uddin K, Guring DR (2010) Land cover change in Bangladesh: a knowledge based classification approach. In: Paper presented at the 10th international symposium on hill mountain remote sensing cartography, Graz: Karl-Franzens University of Graz, Institute of Geography and Regional Science, Kathmandu, Nepal, pp 08-18, 2008

Uddin K, Chaudhary S, Chettri N, Kotru R, Murthy M, Chaudhary RP, Ning W, Shrestha SM, Gautam SK (2015a) The changing land cover and fragmenting forest on the Roof of the World: a case study in Nepal's Kailash Sacred Landscape. Landscape Urban Plan 141:1-10. https:// doi.org/10.1016/j.landurbplan.2015.04.003

Uddin K, Shrestha HL, Murthy M, Bajracharya B, Shrestha B, Gilani H, Pradhan S, Dangol B (2015) Development of 2010 national land cover database for the Nepal. J Environ Manage 148:82-90. https://doi.org/10.1016/j.jenvman.2014.07.047

Uddin K, Abdul Matin M, Maharjan S (2018) Assessment of land cover change and its impact on changes in soil erosion risk in Nepal. Sustainability 10(12):4715. https://doi.org/10.3390/ su10124715

Uddin K, Khanal N, Chaudhary S, Maharjan S, Thapa RB (2020) Coastal morphological changes: assessing long-term ecological transformations across the northern Bay of Bengal. Environmental Challenges 1:100001

Verburg PH, Neumann K, Nol L (2011) Challenges in using land use and land cover data for global change studies. Glob Change Biol 17(2):974-989

Vidal-Macua JJ, Zabala A, Ninyerola M, Pons X (2017) Developing spatially and thematically detailed backdated maps for land cover studies. Int J Digit Earth 10(2):175-206

Wester P, Mishra A, Mukherji A, Shrestha AB (2019) The Hindu Kush Himalaya Assessment. Cham: Springer International Publishing, Basel, Switzerland

Xu J, Sharma R, Fang J, Xu Y (2008) Critical linkages between land-use transition and human health in the Himalayan region. Environ Int 34(2):239-247

Xu J, Grumbine RE, Shrestha A, Eriksson M, Yang X, Wang Y, Wilkes A (2009) The melting Himalayas: cascading effects of climate change on water, biodiversity, and livelihoods. Conserv Biol 23(3):520-530

Zhao L, Zhang P, Ma X, Pan Z (2017) Land cover information extraction based on daily NDVI time series and multiclassifier combination. Mathematical problems in engineering 2017

Ziegler AD, Phelps J, Yuen JQ, Webb EL, Lawrence D, Fox JM, Bruun TB, Leisz SJ, Ryan CM, Dressler W (2012) Carbon outcomes of major land-cover transitions in SE Asia: great uncertainties and REDD + policy implications. Glob Change Biol 18(10):3087-3099 
Open Access This chapter is licensed under the terms of the Creative Commons Attribution 4.0 International License (http://creativecommons.org/licenses/by/4.0/), which permits use, sharing, adaptation, distribution, and reproduction in any medium or format, as long as you give appropriate credit to the original author(s) and the source, provide a link to the Creative Commons license, and indicate if changes were made.

The images or other third party material in this chapter are included in the chapter's Creative Commons license, unless indicated otherwise in a credit line to the material. If material is not included in the chapter's Creative Commons license and your intended use is not permitted by statutory regulation or exceeds the permitted use, you will need to obtain permission directly from the copyright holder.

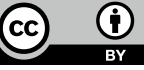

